\title{
Exemestane and Its Active Metabolite 17-Hydroexemestane Induce UDP-Glucuronosyltransferase (UGT) 2B17 Expression in Breast Cancer Cells
}

\author{
Apichaya Chanawong, Peter I Mackenzie, Ross A McKinnon, Dong Gui Hu, ${ }^{1}$ \\ and Robyn Meech ${ }^{1}$
}

Department of Clinical Pharmacology and Flinders Centre for Innovation in Cancer, Flinders University School of Medicine, Flinders Medical Centre, Bedford Park, South Australia, Australia

Received January 20, 2017; accepted March 6, 2017

\begin{abstract}
Exemestane (EXE) is an aromatase inhibitor indicated for endocrine therapy of breast cancer in postmenopausal women. The primary active metabolite of EXE, 17-hydroexemestane (17-HE), is inactivated via glucuronidation, mainly by UDP-glucuronosyltransferase 2B17 (UGT2B17). UGT2B17 also has a primary role in inactivation of endogenous androgens testosterone and dihydrotestosterone and may play an important role in regulation of breast and prostate tumor intracrinology. We recently reported that UGT2B17 could be induced by both estrogenic and androgenic ligands in breast cancer cells via binding of the estrogen receptor $\alpha(\mathrm{ER} \alpha)$ or the androgen receptor (AR) to a complex regulatory unit in the proximal UGT2B17 promoter. In this study we show that both EXE and 17-HE increase UGT2B17 mRNA levels in breast cancer
\end{abstract}

MCF-7 and MDA-MB-453 cells, and increase glucuronidation of UGT2B17 substrates, including 17-HE and androsterone. Using antagonists of $\mathrm{ER} \alpha$ and $\mathrm{AR}$ as well as inhibition mediated by small interfering RNA (siRNA) we demonstrate that EXE and 17-HE induce UGT2B17 expression primarily via the AR. This result is consistent with previous reports that $17-\mathrm{HE}$ can act as an AR ligand. In vitro studies suggest that multiple steroid-responsive DNA elements within the proximal promoter are involved in the response to $17-\mathrm{HE}$-liganded $A R$. The up-regulation of UGT2B17 by EXE and 17-HE in breast cancer cells might enhance the local metabolism of $17-\mathrm{HE}$ as well as that of endogenous androgens, hence impacting potentially on treatment outcomes.

\section{Introduction}

Breast cancer is the most commonly diagnosed cancer in women. Approximately $60 \%$ to $75 \%$ of breast cancers are estrogen receptor $\alpha$ positive $\left(\mathrm{ER} \alpha^{+}\right)($Barnes, 2004) and depend on estrogen for their proliferation (Miller et al., 2008). In postmenopausal women who do not produce ovarian estrogen, conversion of adrenal androgens to estrogens in peripheral tissues and/or locally in breast tissue by aromatase is a key driver of $\mathrm{ER}^{+}$breast cancer cell growth (Yue et al., 1998; Chetrite et al., 2000; Simpson et al., 2002). Aromatase inhibitors are indicated for these patients as first- or second-line therapies (Goss, 2003).

This work was supported by funding from the National Health and Medical Research Council of Australia (ID 1020931 and ID1085410) and the Flinders Medical Centre Foundation, Adelaide Australia. P.I.M. was a NHMRC Senior Principal Research Fellow. R.M. was an Australian Research Council Future Fellow. R.A.M. is a Cancer Council/SA Health Beat Cancer Professorial Chair.

${ }^{1}$ D.G.H. and R.M. were co-senior authors.

https://doi.org /10.1124/jpet.117.240317.
Exemestane is a steroidal (type I) aromatase inhibitor that is structurally related to the natural aromatase substrate 4 -androstenedione. It is a mechanism based inactivator that binds irreversibly to the active site of aromatase. Postmenopausal patients with early stage $\mathrm{ER} \alpha^{+}$breast cancer typically receive 2 to 3 years of tamoxifen followed by 2 to 3 years of exemestane (EXE) for a total of 5 years of hormone therapy (Coombes et al., 2004; van de Velde et al., 2011). This regimen has been shown to improve relapse-free survival over continuing tamoxifen therapy (Miller et al., 2008; van de Velde et al., 2011). Exemestane may also be used as primary therapy for early stage invasive breast cancer (Ruddock and Molinari, 2006; Miller et al., 2008), and for advanced metastatic breast cancer that has progressed after tamoxifen therapy (Lonning and Geisler, 2008; Walker et al., 2013).

Exemestane is converted into an active metabolite 17hydroexemestane (17-HE), which has comparable antiaromatase activity to EXE (Kamdem et al., 2011). In addition to binding to aromatase, $17-\mathrm{HE}$ binds weakly to $\mathrm{ER} \alpha$ and with moderate/high affinity to the androgen receptor (AR). The majority (67\%-88\%) of $\mathrm{ER}^{+}{ }^{+}$breast cancers express the $\mathrm{AR}$

ABBREVIATIONS: 17-HE, 17-hydroexemestane; AR, androgen receptor; BIC, bicalutamide; DCC-FBS, dextran-coated charcoal-stripped fetal bovine serum medium; DHT, dihydrotestosterone; ER, estrogen receptor; ERE, estrogen response element; ERU, estrogen response unit; EXE, exemestane; FBS, fetal bovine serum; FOXA1, Foxhead box A1; FUL, fulvestrant; GAPDH, glyceraldehyde 3-phosphate dehydrogenase; Mt, mutated construct; qRT-PCR, quantitative reverse-transcription polymerase chain reaction; siRNA, small interfering RNA; SNP, single-nucleotide polymorphism; UGT, UDP-glucuronosyltransferase. 
(Moinfar et al., 2003; Hu et al., 2011; Loibl et al., 2011). 17-HE was reported to induce proliferation and gene activation at micromolar concentrations through ER in both MCF7 and T47D breast cancer cell lines, and via AR at low nanomolar concentrations selectively in T47D cells (Ariazi et al., 2007). It has been suggested that circulating levels of 17-HE (representing approximately $10 \%$ of the parent compound in serum; Evans et al., 1992) may be sufficient to regulate AR-dependent activities that decrease bone density loss (Ariazi et al., 2007). Moreover, 17-HE is reported to inhibit breast cancer cell survival by mechanisms different from those of EXE (Amaral et al., 2015); it is possible that this involves AR-agonism.

UDP-glucuronosyltransferase enzymes (UGT) constitute a superfamily responsible for the glucuronidation and inactivation of numerous therapeutic drugs and endobiotics, including steroid hormones. The major EXE metabolite found in human urine is the inactive glucuronide of $17-\mathrm{HE}$. In vitro studies demonstrate that UGT1A4, 2B17, 1A8, and 1A10 are all able to glucuronidate 17-HE, with UGT2B17 showing the highest activity (Sun et al., 2010). Supporting the primary role of UGT2B17 in EXE metabolism, UGT2B17 expression levels correlate strongly with 17-HE-glucuronide production in liver microsomes (Sun et al., 2010). Moreover, patients with the UGT2B17 null genotype showed lower levels of 17-HEglucuronide in plasma (Chen et al., 2016). UGT1A4 and UGT2B17 are abundant in the liver, and UGT1A 8 and UGT1A10 are predominantly expressed in the gastrointestinal tract. UGT2B17, UGT1A8, and UGT1A10 are also expressed at varying levels in normal and cancerous breast tissues (Thibaudeau et al., 2006; Nakamura et al., 2008; Starlard-Davenport et al., 2008; Zhu et al., 2016) and could be involved in intratumoral conjugation of 17-HE.

UGT2B17 and its paralog UGT2B15 conjugate androgens, including testosterone and dihydrotestosterone (DHT) (Chen et al., 1993; Beaulieu et al., 1996). UGT2B17 and UGT2B15 are widely expressed (Levesque et al., 1997; Tchernof et al., 1999; Nakamura et al., 2008; Ohno and Nakajin, 2009; Jones and Lazarus, 2014), including in sex hormone-sensitive tissues, which suggests a role in maintaining intratissular hormone homeostasis. Indeed, UGT2B17 and UGT2B15 expression and function are linked to the risk of developing androgen-sensitive prostate diseases (Barbier and Belanger, 2008; Gauthier-Landry et al., 2015). We recently showed that high intratumoral UGT2B17 and UGT2B15 expression levels correlate with better survival outcomes in distinct genetic subgroups of breast cancer (Hu et al., 2016) although how this relates to altered intratumoral steroid metabolism remains to be determined.

We previously defined a conserved 282 base-pair region of the $U G T 2 B 17$ and $U G T 2 B 15$ proximal promoters as an estrogen response unit (ERU) that binds to $\mathrm{ER} \alpha$ and mediates induction by estrogens in a manner dependent on foxhead box A1 (FOXA1) (Hu and Mackenzie, 2009). More recently we determined that the ERU can mediate both estrogenic and androgenic responses in breast cancer cells via binding to both $\mathrm{ER} \alpha$ and $\mathrm{AR}$ in a FOXA1-dependent manner (Hu et al., 2016). In the present study, we demonstrate that both EXE and 17-HE up-regulate UGT2B17 and UGT2B15 expression in breast cancer cells. Analysis of the UGT2B17 promoter indicates that induction by EXE/17-HE is mediated by recruitment of AR to the ERU. We propose that induction of $U G T 2 B 17$ could facilitate intratumoral inactivation of $17-\mathrm{HE}$; moreover, induction of both $U G T 2 B 17$ and $U G T 2 B 15$ could alter tumor intracrinology, possibly impacting on cancer progression.

\section{Materials and Methods}

Chemicals. Analytic grade chemicals including EXE, bicalutamide (BIC), and fulvestrant (FUL) were purchased from Sigma-Aldrich (St. Louis, MO). 17-HE (17 $\beta$-hydroxy-6-methyleneandrosta-1,4dien-3one) was purchased from Toronto Research Chemicals (North York, ON, Canada).

Cell Culture and Drug Treatment, RNA Extraction, and Reverse Transcriptase Quantitative Real-time Polymerase Chain Reaction. MCF-7 and MDA-MB-453 breast cancer cell lines were maintained in RPMI 1640 medium (Life Technologies, Grand Island, NY) supplemented with 5\% (v/v) fetal bovine serum (FBS) at $37^{\circ} \mathrm{C}$ and $5 \% \mathrm{CO}_{2}$. Cell lines were cultured in phenol-red free RPMI 1640 medium supplemented with 5\% dextran-coated charcoalstripped fetal bovine serum (DCC-FBS) medium for 3 days before treatment with various drugs for 24 hours. Total RNA was isolated using TRIzol reagent (Life Technologies) and reverse transcribed using reagents from Invitrogen (Mulgrave, VIC, Australia) as previously described elsewhere (Hu and Mackenzie, 2009). Real-time quantitative reverse-transcription chain reaction (qRT-PCR) was performed using the RotorGene 3000 (Corbett Research, NSW, Australia), and GoTaq qPCR master mix (Promega, Madison, WI). Sequences of polymerase chain reaction primers that amplify $18 \mathrm{~S}$ rRNA, UGT1A4, UGT1A8, UGT1A10, UGT2B15, UGT2B17, and glyceraldehyde 3-phosphate dehydrogenase (GAPDH) were reported elsewhere (Hu and Mackenzie, 2009; Hu et al., 2010).

Data were analyzed using the delta-delta cycle threshold method (Livak and Schmittgen, 2001), mRNA levels of target genes were normalized to the levels of 18S rRNA in the same sample, and the fold change in mRNA levels after drug treatment is presented relative to levels in vehicle-treated cells (set as a value of 1 ). All treatments were performed in triplicate.

Glucuronidation Assays. MCF-7 cells were treated in duplicate with vehicle ( $0.1 \%$ dimethylsulfoxide), $100 \mathrm{nM}$ EXE, or $10 \mathrm{nM} 17-\mathrm{HE}$ for 72 hours. Whole-cell lysates were harvested in TE buffer $(10 \mathrm{mM}$ Tris-HCl, 1 mM EDTA, pH 7.6). Protein concentrations were determined using the Bradford protein assay (Bio-rad, Hercules, CA). Androsterone glucuronidation assays were performed by incubating $100 \mu \mathrm{l}$ of reaction mixture containing $0.2 \mathrm{mM}$ UDP-glucuronic acid (Sigma-Aldrich), 319 pmol of $\left[{ }^{14} \mathrm{C}\right] \mathrm{UDP}$-glucuronic acid (PerkinElmer, Boston, MA), $0.2 \mathrm{mM}$ androsterone, $100 \mathrm{mM}$ potassium phosphate ( $\mathrm{pH}$ 7.5 ), and $4 \mathrm{mM} \mathrm{MgCl}_{2}$ with cell lysates containing $450 \mu \mathrm{g}$ of protein at $37^{\circ} \mathrm{C}$ for 2 hours. The 17-HE glucuronidation assays were performed under the same conditions using $0.2 \mathrm{mM}$ 17-hydroexemestane as substrate.

Reactions were terminated by addition of $200 \mu \mathrm{l}$ of ethanol and centrifugation at $12,000 \mathrm{rpm}$ for 5 minutes. We applied $100 \mu \mathrm{l}$ of supernatant from each sample to a thin-layer chromatography plate (250 $\mu \mathrm{m}$ silica gel; TLC Uniplates; Analtech, Newalk, DE). Human UGT2B17 supersomes (In Vitro Technologies, Noble Park North, VIC, Australia) were included as positive controls in each assay. Chromatography and quantification of glucuronide band intensities were conducted as previously reported (Chanawong et al., 2015; Wijayakumara et al., 2015). Fold induction of glucuronidation activity in drugtreated cells was calculated relative to vehicle-treated cells.

Knockdown of Gene Expression Using Small Interfering RNA. ON-TARGETplus SMARTpools targeting $\mathrm{ER} \alpha(\operatorname{siER} \alpha)$, AR (siAR), FOXA1 (siFOXA1), and a nontargeting control small interfering RNA (siRNA) pool (siCtr), were purchased from Dharmacon RNAi technologies (Lafayette, CO). MCF7 cells $\left(5 \times 10^{5}\right.$ cells per well) were plated in six-well plates and transiently transfected with either siCtr, $\operatorname{siER} \alpha, \operatorname{siAR}$, or $\operatorname{siFOXA} 1$ at $100 \mathrm{nM}$ using $8 \mu$ l Lipofectamine 2000 (Invitrogen) as described previously elsewhere ( $\mathrm{Hu}$ and 
TABLE 1

Wild-type and mutated ERE sequences of UGT2B17 promoter constructs used in this study Motifs are underlined and boldfaced.

\begin{tabular}{ll}
\hline & \multicolumn{1}{c}{ Nucleotide sequence (5' to $\left.3^{\prime}\right)$} \\
\hline WT 3'ERE & CTAAAATAAATATGAGGTCAACTCAAATTTTAGCAG \\
Mt 3'ERE & CTAAAATAAATATGACTCGCACTCAAATTTTAGCAG \\
WT 5'ERE & TACTTACATATTCTAGGTCATAAAAATTATTGCT \\
Mt 5'ERE & TACTTACATATTCTA CAGCGTAAAAATTATTGCT \\
WT Imperfect ERE & TACTTCTTCTCTCTATGTCAAGGGCACCGAACAGG \\
Mt Imperfect ERE & TACTTCTTCTCTCTA $\overline{\text { ATTACAGGGCACCGAACAGG }}$ \\
\hline
\end{tabular}

Mt, mutated construct; WT, wild type.

Mackenzie, 2009). Twenty-four hours after transfection, the media were replaced with phenol-red free RPMI supplemented with $5 \%$ DCC-FBS. Forty-eight hours after transfection, cells were treated with EXE, 17-HE, or vehicle in quadruplicate. Twenty-four hours after drug treatment three wells from each condition were harvested for RNA preparation and gene expression analysis by qRT-PCR. The cells of the fourth wells of each condition were cultured for an additional 24 hours; cell lysates then were prepared using radioimmunoprecipitation assay buffer.

Western Blot Analysis. Twenty micrograms of total protein from each sample were separated in 10\% SDS-polyacrylamide gels and transferred to nitrocellulose membranes (Bio-Rad Laboratories, Hercules, CA) for immunodetection. Membranes were probed with primary antibodies including anti-ER (HC-20), anti-AR (N-20) (Santa Cruz Biotechnology, Dallas, TX), anti-FOXA1 (Ab23738; Abcam, Cambridge, MA) followed by horseradish peroxidase-conjugated donkey anti-rabbit secondary antibody (Neomarker, Fremont, CA). The same membranes were reprobed with GAPDH antibody (Sigma Aldrich) followed by secondary antibody as mentioned earlier. Immunosignals were detected with the SuperSignalWest Pico Chemiluminescent kit (Thermo-Fisher Scientific, Waltham, MA) and an ImageQuant LAS 4000 luminescent image analyzer (GE Healthcare, Chalfont St. Giles, United Kingdom). Quantitation of band intensity and background subtraction were performed using MultiGauge version 3.0 (Fujifilm Corporation, Tokyo, Japan) as described elsewhere (Chanawong et al., 2015).

Transient Transfection and Luciferase Reporter Assay. Two wild-type $U G T 2 B 17$ proximal promoter-pGL3 luciferase reporter constructs containing nucleotides -2 to -694 of $U G T 2 B 17$ and bearing either the common " $\mathrm{A}$ " allele or the rarer " $\mathrm{G}$ " allele within the polymorphic FOXA1 motif were described elsewhere (Hu et al., 2010). The cloned promoter region contains one FOXA1-binding site, two estrogen response element (ERE) half-sites, and one imperfect ERE site. The previously reported FOXA1 mutated 2B17-694/-2 promoter-reporter construct was also used in this study (Hu et al., 2010).

As shown in Fig. 6A, this study generated seven additional $2 B 17$ 694/-2 mutated constructs (Mt) using the QuickChange site-directed mutagenesis kit (Stratagene, La Jolla, CA), including mutation of a single ERE site (2B17 Mt-3'ERE half-site [2B17 Mt-S1-ERE], 2B17 Mt-5'ERE half-site [2B17 Mt-S2-ERE], and 2B17 Mt-Imperfect ERE [2B17 Mt-S3-ERE]), mutation of two ERE sites simultaneously (2B17 Mt-3'ERE half-site and 5'ERE half-site [2B17 Mt-D1-ERE], 2B17 Mt-3'ERE half-site and imperfect ERE site [2B17 Mt-D2-ERE], and 2B17 Mt 5'ERE half-site and imperfect ERE site [2B17 Mt-D3-ERE]), and mutation of three ERE sites simultaneously (2B17 Mt-3'ERE
A

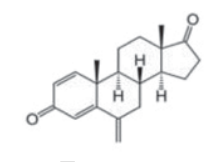

Exemestane

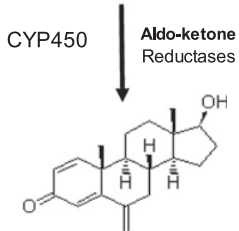

17-hydroexemestane

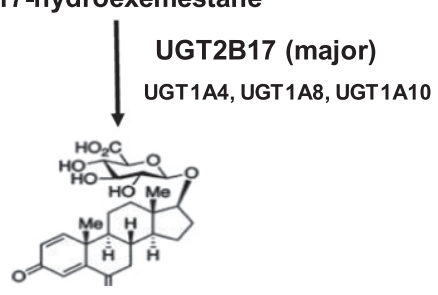

17-hydroexemestane-0-glucuronide
B

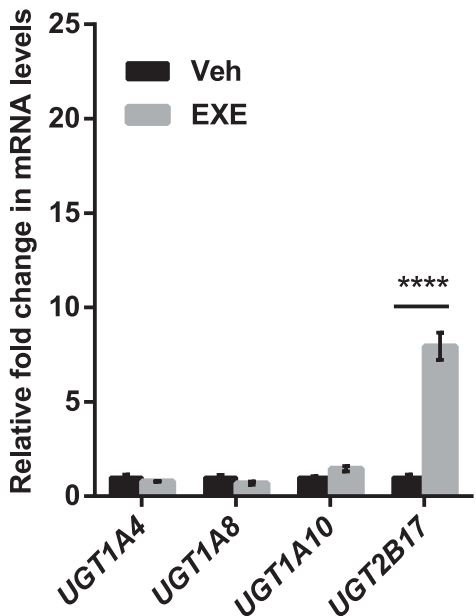

C

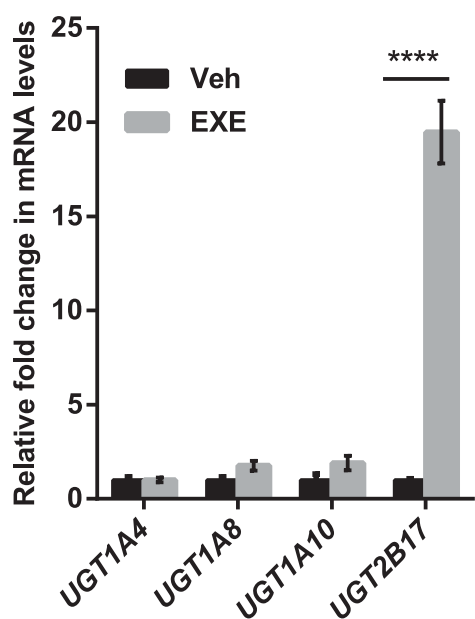

Fig. 1. (A) The structure of EXE and its primary active metabolite 17-HE and the identities of enzymes involved in their metabolism. (B, C) Effects of EXE on expression of UGTs that inactivate 17-HE in MCF7 cells. MCF-7 cells maintained in (B) RPMI medium supplemented with 5\% FBS (V/V) or (C) RPMI medium supplemented with 5\% DCC-FBS were treated in triplicate for 24 hours with $100 \mathrm{nM}$ EXE or vehicle (Veh, $0.1 \%$ dimethylsulfoxide), and gene expression was assessed by real-time qRT-PCR as described in Materials and Methods. After normalizing to 18S rRNA, the mRNA levels of target genes in EXE-treated cells are presented as the fold change relative to the mRNA levels of the respective genes in the vehicle-treated cells (set as a value of 1) from two independent experiments. (*Statistically significant differences between vehicle and EXE treatment, using two-way analysis of variance, Tukey post hoc analysis. ${ }^{* * * *} P \leq 0.0001$.) 


\section{A $\mathrm{MCF}-7$}

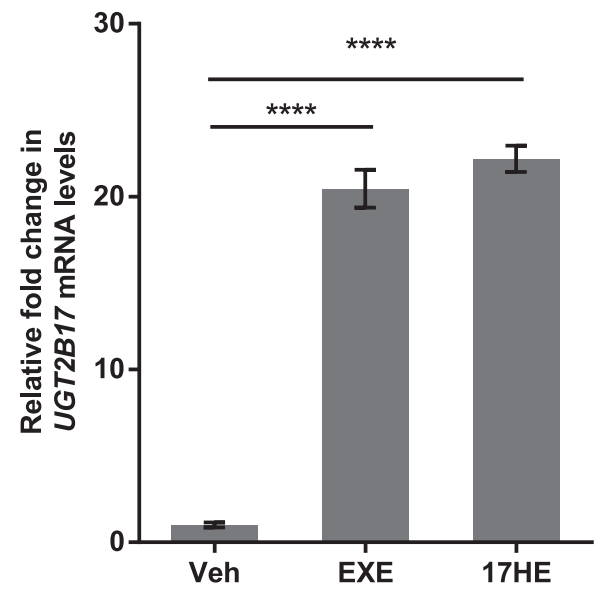

\section{MCF-7, EXE}

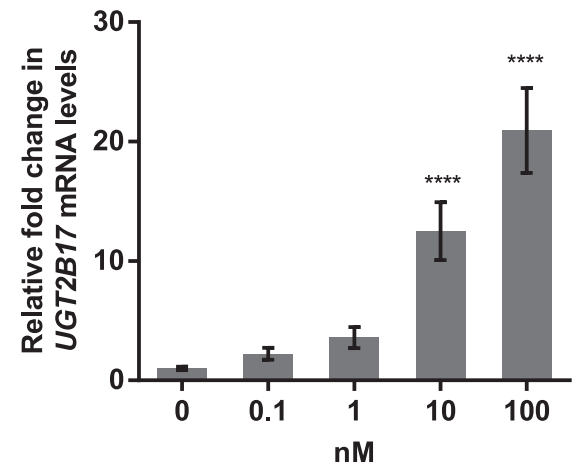

B MDA-MB453

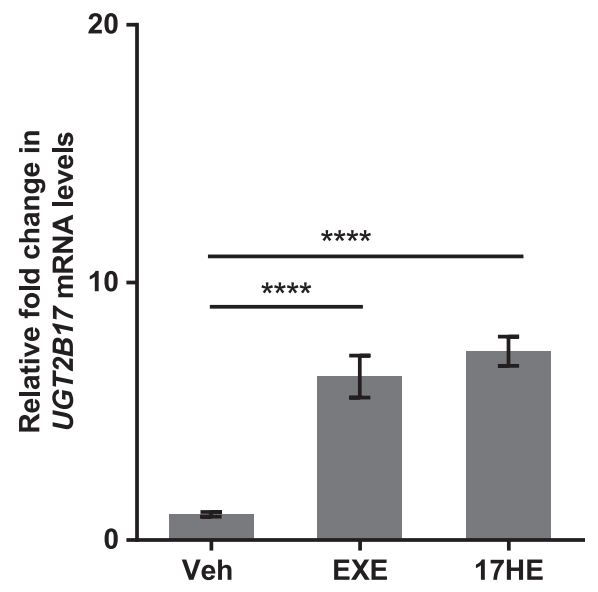

D MCF-7, 17HE

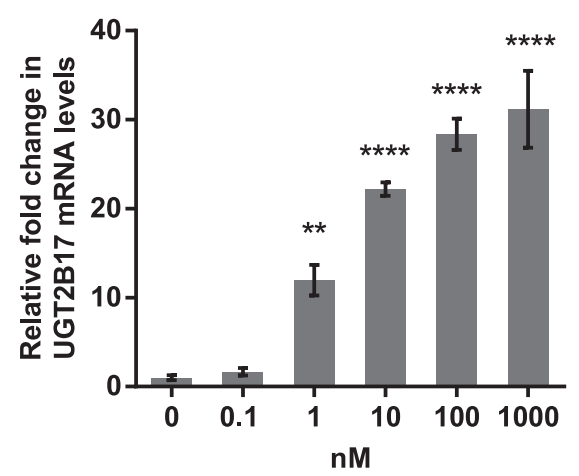

Fig. 2. Both EXE and 17-HE elevate UGT2B17 mRNA levels in MCF-7 and MDA-MB-453 breast cancer cells. (A) MCF-7 cells and (B) MDA-MB453 cells were maintained in RPMI medium supplemented with 5\% DCC-FBS and then treated with $100 \mathrm{nM}$ EXE, $10 \mathrm{nM}$ 17 -HE, or vehicle (Veh, $0.1 \%$ dimethylsulfoxide) for 24 hours; gene expression was assessed by real-time qRT-PCR. The dose dependence of UGT2B17 mRNA induction in MCF7 cells by (C) EXE and (D) 17-HE was assessed over a 4-fold log range. Data shown are fold induction (mean \pm S.E.M.) of target mRNA levels from drug-treated MCF7 cells over vehicle-treated performed in triplicate from two independent experiments. (Statistical analyses used oneway analysis of variance followed by Tukey's post hoc analysis. $* P \leq 0.05, * * P \leq 0.01$, $* * * P \leq 0.001, * * * * P \leq 0.0001$.) half-site, 5'ERE half-site and imperfect ERE site [2B17 Mt-T1]). The sequences of the wild-type and mutated ERE motifs are shown in Table 1 . The sequences of all promoter-reporter constructs were confirmed by DNA sequencing.

MCF-7 cells were seeded into 96 -well plates at a density of $3 \times 10^{4}$ cells/well in phenol red-free RPMI supplemented with 5\% DCC-FBS. After culture overnight, cells were transfected with $100 \mathrm{ng}$ of wild-type or mutated promoter-reporter constructs combined with $2 \mathrm{ng}$ of the control pRL-null (Renilla) vector using $0.4 \mu \mathrm{l}$ of Lipofectamine 2000 (Invitrogen). Six hours after transfection, the transfection medium was replaced with fresh medium containing $100 \mathrm{nM}$ EXE, $10 \mathrm{nM} 17-\mathrm{HE}$, or vehicle (0.1\% dimethylsulfoxide). Cells were harvested after 48 hours in passive lysis buffer, and firefly luciferase and Renilla luciferase activities were analyzed using the Dual-Glo Luciferase Reporter Assay System (Promega, Madison, WI) as described previously elsewhere (Hu and Mackenzie, 2010). Firefly activities were normalized to Renilla activities, and then the activity of each promoter-reporter construct was normalized to that of the empty pGL3 basic vector within each treatment group. The fold induction of the promoter activities after drug treatment was calculated by normalization to the vehicle treatment of each promoterreporter construct.

Statistical Analysis. Statistical analysis was performed using one-way or two-way analysis of variance followed by Tukey's post hoc

\section{A Androsterone}

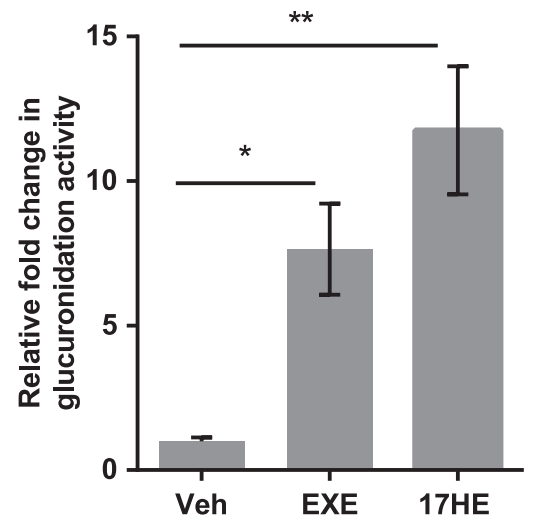

\section{B 17-hydroexemestane}

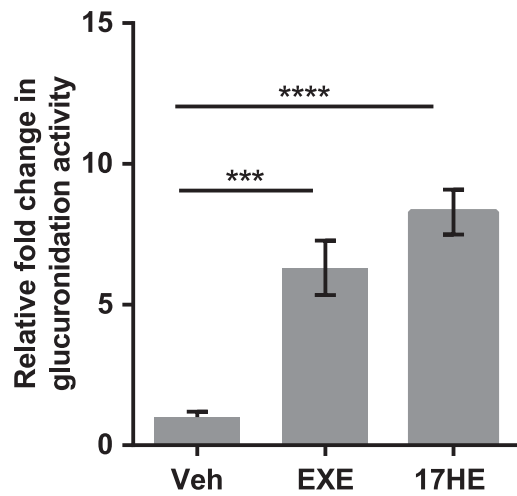

Fig. 3. Both EXE and 17-HE increase androsterone and 17-HE glucuronidation activities in breast cancer cells. MCF-7 cells were treated with $100 \mathrm{nM}$ EXE, $10 \mathrm{nM} 17-\mathrm{HE}$, or vehicle (Veh, $0.1 \%$ dimethylsulfoxide) for 72 hours then subjected to glucuronidation assays as described in Materials and Methods. (A) Androsterone and (B) 17-HE glucuronidation activity in cells treated with EXE or 17-HE is shown relative to glucuronidation activity in vehicle-treated cells (set to 1). Data are the average of two independent experiments performed in duplicate. (*Statistically significant differences between vehicle and ligands treatment, using one-way analysis of variance, Tukey post hoc analysis. $* P \leq 0.05, * * P \leq 0.01$, ***P $\leq$ $0.001, * * * * P \leq 0.0001$.) 
test, as indicated in the figure legends. $P \leq 0.05$ was considered statistically significant.

\section{Results}

EXE Induces Expression of UGT2B17 in MCF7 Breast Cancer Cells. Previous work has shown that UGT2B17, UGT1A4, UGT1A8, and UGT1A10 conjugate 17-HE, the main active metabolite of EXE, with UGT2B17 having the highest catalytic activity (Sun et al., 2010) (Fig. 1A). UGT enzymes are frequently induced by molecules that they metabolize as part of a regulatory feedback loop; hence, we considered the possibility that some of these UGT enzymes might also be induced by EXE. To test this hypothesis, MCF-7 cells maintained in either standard medium (Fig. 1B) or steroid-reduced medium (Fig. 1C) were treated with EXE (100 nM), and we assessed the mRNA levels of the four UGT enzymes responsible for exemestane-17-O-glucuronide formationUGT2B17, UGT1A4, UGT1A8, and UGT1A10. EXE significantly increased the level of UGT2B17 mRNA but not that of
UGT1A4, UGT1A8, or UGT1A10 (Fig. 1). Interestingly we recently showed that UGT2B17, which in addition to the liver is expressed in steroid-responsive tissues and tumors, is induced by both estrogenic and androgenic signaling cascades in breast cancer cells (Hu et al., 2016). In contrast, the other UGT enzymes discussed here have not shown significant induction by steroid signaling in our previous work. The active EXE metabolite 17-HE can act as both a weak estrogenic and strong androgenic ligand, suggesting that this metabolite might induce UGT2B17 via either ER or AR signaling.

To begin to assess whether the estrogenic or androgenic function of the EXE metabolite 17-HE might be responsible for induction of UGT2B17, we treated both $\mathrm{ER}^{+} / \mathrm{AR}^{+} \mathrm{MCF} 7$ and $\mathrm{ER}^{-} / \mathrm{AR}^{+} \mathrm{MDA}-\mathrm{MB}-453$ breast cancer cells with EXE $(100 \mathrm{nM})$ or 17-HE (10 nM). Both drugs elevated UGT2B17 mRNA levels in both cell lines in a dose-dependent manner (Fig. 2). Moreover, both EXE and 17-HE increased androsterone and 17-HE glucuronidation activities in MCF7 cells, indicating an increase in functional UGT2B17 protein (Fig. 3). The ability of EXE and 17-HE to induce UGT2B17 expression

\section{A EXE}

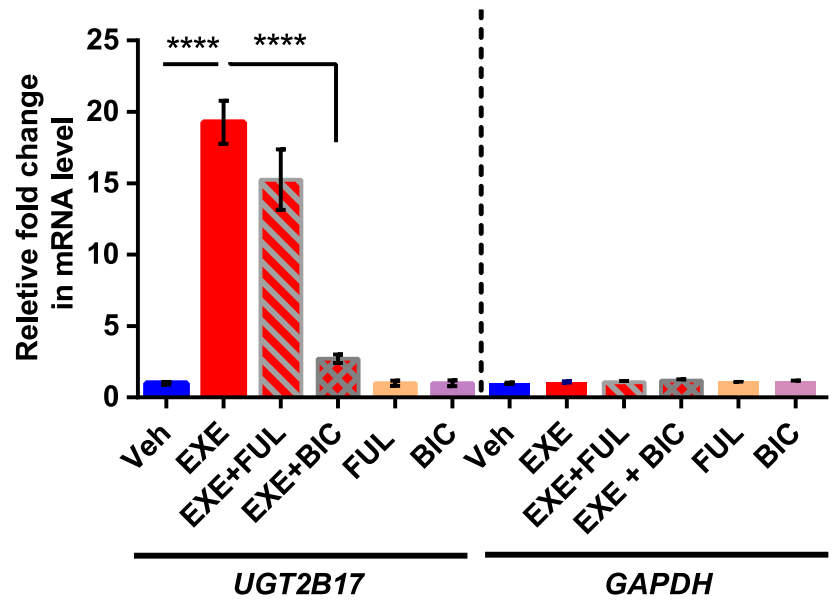

C

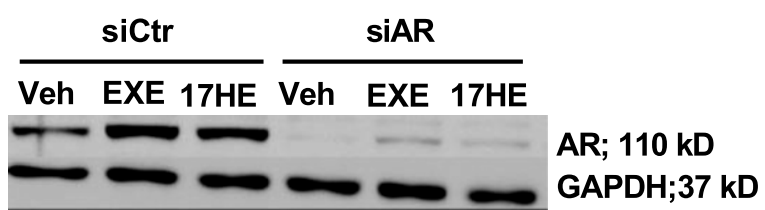

\section{B 17HE}

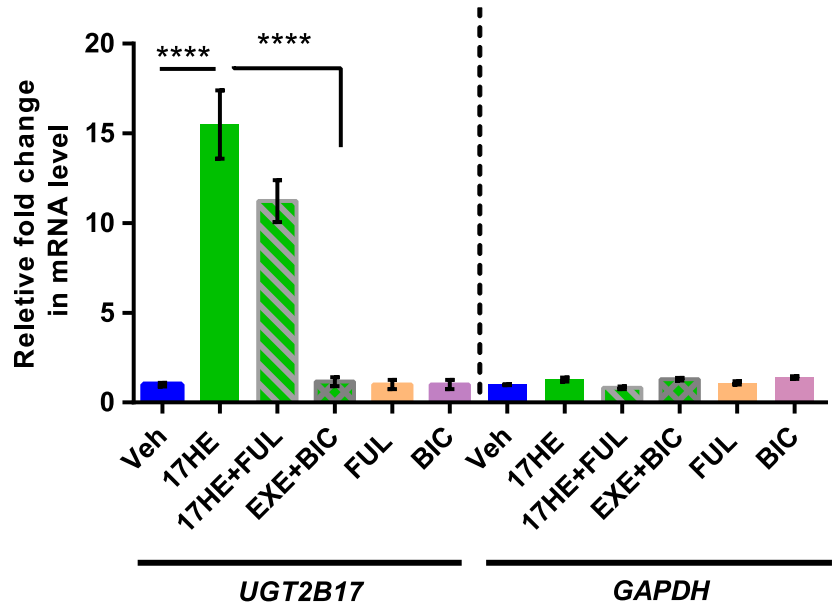

D

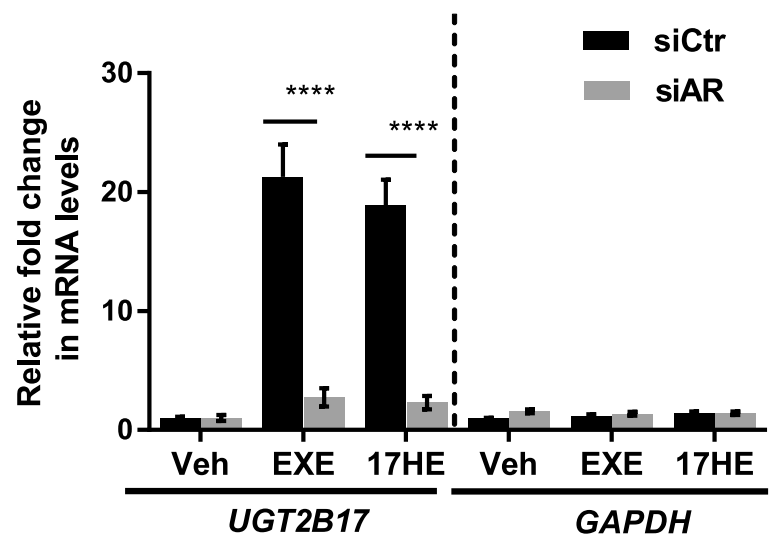

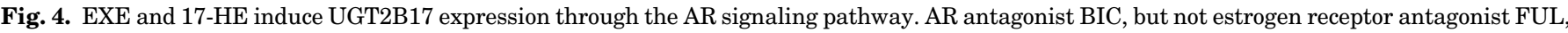

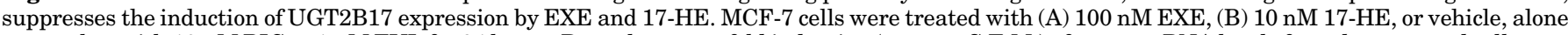

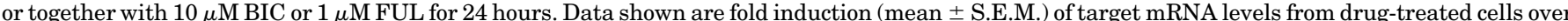

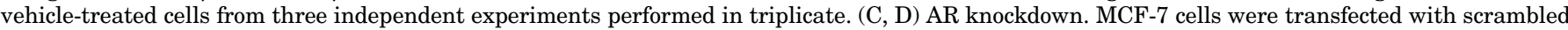

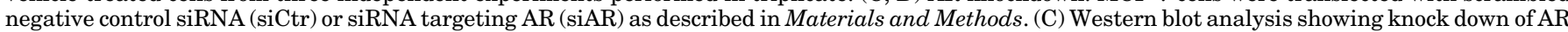

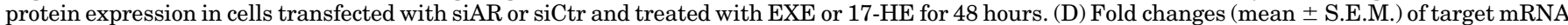

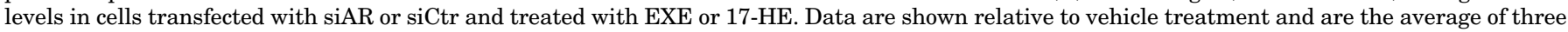

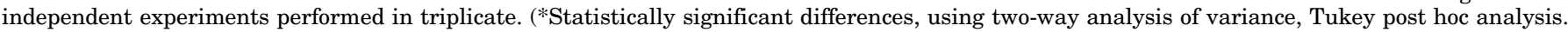
$* * * * P \leq 0.0001$.) 
in $\mathrm{ER}^{-} / \mathrm{AR}^{+} \mathrm{MDA}-\mathrm{MB}-453$ cells suggests a primary role for the androgen receptor signaling pathway.

The AR antagonist BIC and the $\mathrm{ER} \alpha$ antagonist FUL were used to assess the relative role of $\mathrm{ER}$ and $\mathrm{AR}$ in induction of UGT2B17 expression by EXE and 17-HE. In MCF-7 cells BIC $(10 \mu \mathrm{M})$ but not FUL $(1 \mu \mathrm{M})$ blocked induction of UGT2B17 by both drugs, suggesting the specific involvement of AR (Fig. 4A and 4B). Consistent with this interpretation, knockdown of AR with siRNA (Fig. 4C) led to almost complete inhibition of EXEand 17-HE-mediated induction of UGT2B17 mRNA (Fig. 4D).

Our recent work showed a critical role for FOXA1 in the induction of UGT2B17 by estrogenic and androgenic ligands (estradiol, tamoxifen, dihydrotestosterone, enobosarm) (Hu et al., 2016), so we examined whether FOXA1 may play a role in induction of UGT2B17 by EXE/17-HE. FOXA1 siRNA dramatically reduced but did not abolish induction of UGT2B17 by both drugs (Fig. 5B); the residual activation may be due to incomplete inhibition of FOXA1 expression (Fig. 5A).

To define the region of the UGT2B17 promoter that is involved in induction by EXE/17-HE, we used UGT2B17 promoter-reporter constructs containing 694 base pairs of the proximal promoter including the previously defined ERU (Hu et al., 2016). Mutated reporter constructs (Mt) were used that contain mutations in the FOXA1-binding motif and the three ER/AR-binding motifs (imperfect ERE, 5'ERE half-site, 3'ERE half-site) (Fig. 6A). In addition, we used a UGT2B17 promoter construct that contains a naturally occurring singlenucleotide polymorphism (SNP) in the FOXA1 motif that is referred to as the $\mathrm{G}$ allele (the most common allele has an $\mathrm{A}$ residue at this position). Previous work showed that the
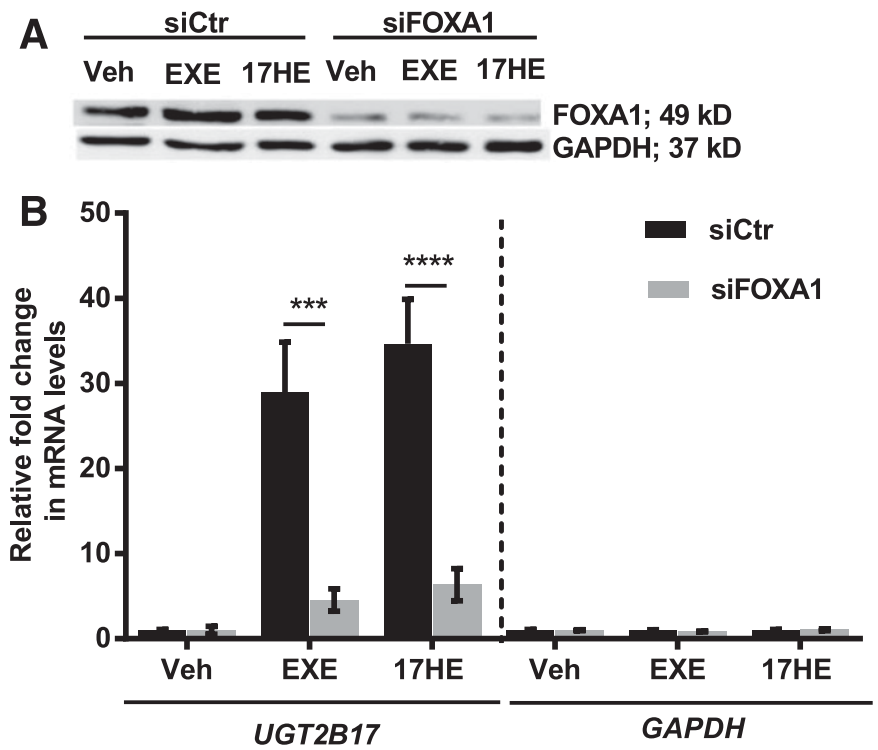

Fig. 5. FOXA-1 is required for EXE- and 17-HE-mediated induction of UGT2B17. MCF-7 cells were transfected with scrambled siRNA (siCtr) or siRNA targeting FOXA1 (siFOXA1) as described in Materials and Methods. (A) Western blot analysis showing knock down of FOXA1 protein expression after transfection of siCtr or siFOXA1 and treatment with EXE, 17-HE, or vehicle for 48 hours. (B) Fold changes (mean \pm S.E. M.) of target mRNA levels after transfection of siCtr or siFOXA1 and treatment with EXE or 17-HE. Data are shown relative to vehicle control and are the average of three independent experiments performed in triplicate. (*Statistically significant differences, using two-way analysis of variance, Tukey post hoc analysis. $* * * P \leq 0.001, * * * * P \leq 0.0001$.) presence of the $\mathrm{G}$ residue in the motif reduced binding of FOXA1 (Hu et al., 2010). The wild-type promoter construct was activated 4 - to 5 -fold by both ligands (Fig. 6 , B and C). The promoter containing the FOXA1 $\mathrm{G}$ allele was not activated by EXE/17-HE, and neither was the construct with the mutated FOXA1 motif. Mutation of single ERE motifs modestly reduced activation; double mutations of the EREs reduced activation further, and the triple ERE mutation abolished activation (Fig. 6, B and C).

Our previous work showed that UGT2B17 and UGT2B15 are regulated similarly by estrogens and androgens via the highly conserved ERU (Hu et al., 2016). To assess whether EXE and 17-HE also induce UGT2B15 and whether the mechanism may be the same for UGT2B15 and UGT2B17, we treated MCF-7 (Fig. 7A) and MDA-MB-453 (Fig. 7B) breast cancer cells with EXE (100 nM) or 17-HE (10 nM), with or without BIC or FUL. UGT2B15 mRNA expression was induced by both drugs, and this was suppressed by BIC but not FUL (Fig. 7C). Similarly, siRNA targeting AR (siAR) but not siRNA targeting $\mathrm{ER} \alpha$ (si-ER $\alpha$ ) inhibited induction (Fig. 7D). Small interfering RNA targeting FOXA1 also inhibited induction by EXE and 17-HE, suggesting that induction of $U G T 2 B 17$ and $U G T 2 B 15$ by these drugs involves very similar molecular mechanisms.

\section{Discussion}

We recently showed that $U G T 2 B 17$ and $U G T 2 B 15$ are regulated in $\mathrm{ER}^{+} / \mathrm{AR}^{+}$breast cancer cells by estrogenic and androgenic ligands via binding of $\mathrm{ER} \alpha$ and AR to a response unit in the proximal promoters of both genes that we named the ERU ( $\mathrm{Hu}$ and Mackenzie, 2009; Hu et al., 2016). In the current study, we found that UGT2B17 (and UGT2B15) could be induced by EXE and its active metabolite 17-HE. Consistent with the previous observation that 17-HE could act as an AR agonist with high nanomolar affinity, 17-HE induced these genes specifically through the AR. The affinity of EXE for AR (measured by competitive binding assays) is approximately 100-fold lower than that of 17-HE (Ariazi et al., 2007); hence, the ability of EXE to potently induce UGT2B17/UGT2B15 at only 10 -fold higher concentration than $17-\mathrm{HE}$ suggests that it is at least partially converted to $17-\mathrm{HE}$ within the breast cancer cell lines.

17-HE is known to be formed in liver predominantly by cytochrome P450 enzymes 1A1/2 (Kamdem et al., 2011) and aldo-keto reductases (Sun et al., 2011). The conversion of EXE to $17-\mathrm{HE}$ is likely to also occur in breast tissue and breast cancer cell lines where these enzymes are expressed (GothGoldstein et al., 2000; Penning and Byrns, 2009; Rodriguez and Potter, 2013; Yin et al., 2014). The relative roles of cytochrome $\mathrm{P} 450$ and aldo-keto reductase enzymes in the production of 17-HE in the breast cancer cell lines used in this study is a subject for further investigation.

The UGT2B17/UGT2B15 ERU contains three ERE-like motifs that we previously named the imperfect ERE, $5^{\prime} \mathrm{ERE}$ half-site, and 3'ERE half-site, as well as a FOXA1-binding site. We previously showed that the FOXA1 motif was important for AR activity (Hu et al., 2016) and that the G allele SNP in the FOXA1 motif impaired FOXA1 binding. Consistent with this, a UGT2B17 promoter construct containing the $\mathrm{G}$ allele sequence was not induced by $17-\mathrm{HE}$. Of note, both MCF7 and MDA-MB-453 cells are homozygous for the 


\section{A} UGT2B17-694 WT
UGT2B17-694 Mt-FOXA1
UGT2B17-694 Mt-S1-ERE

\section{B}

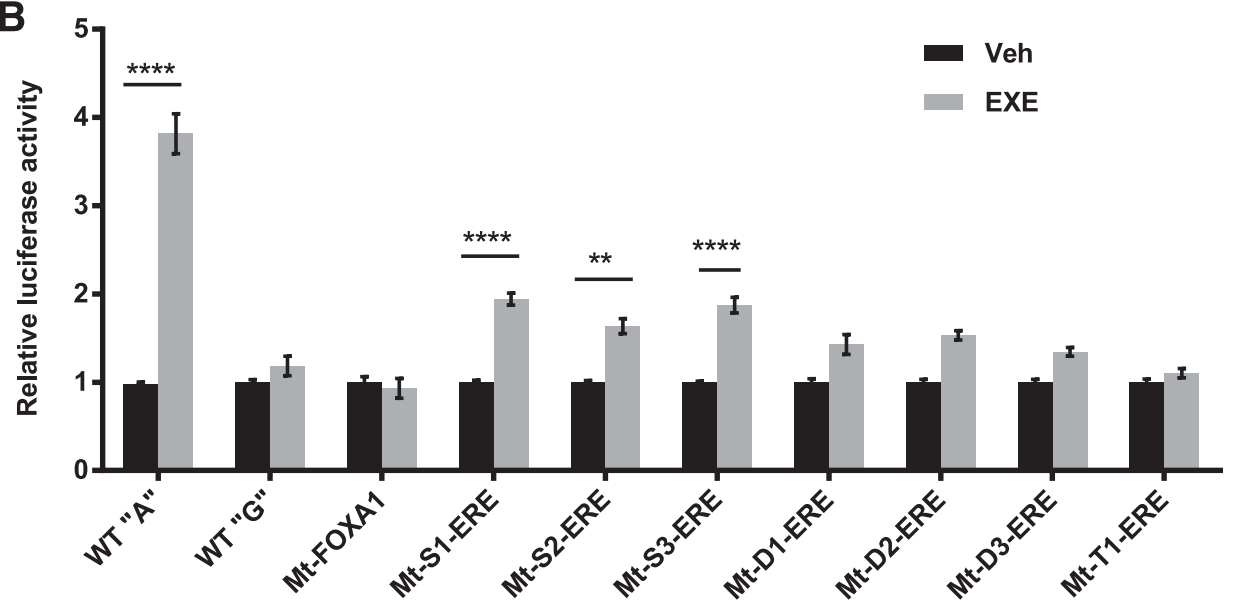

C

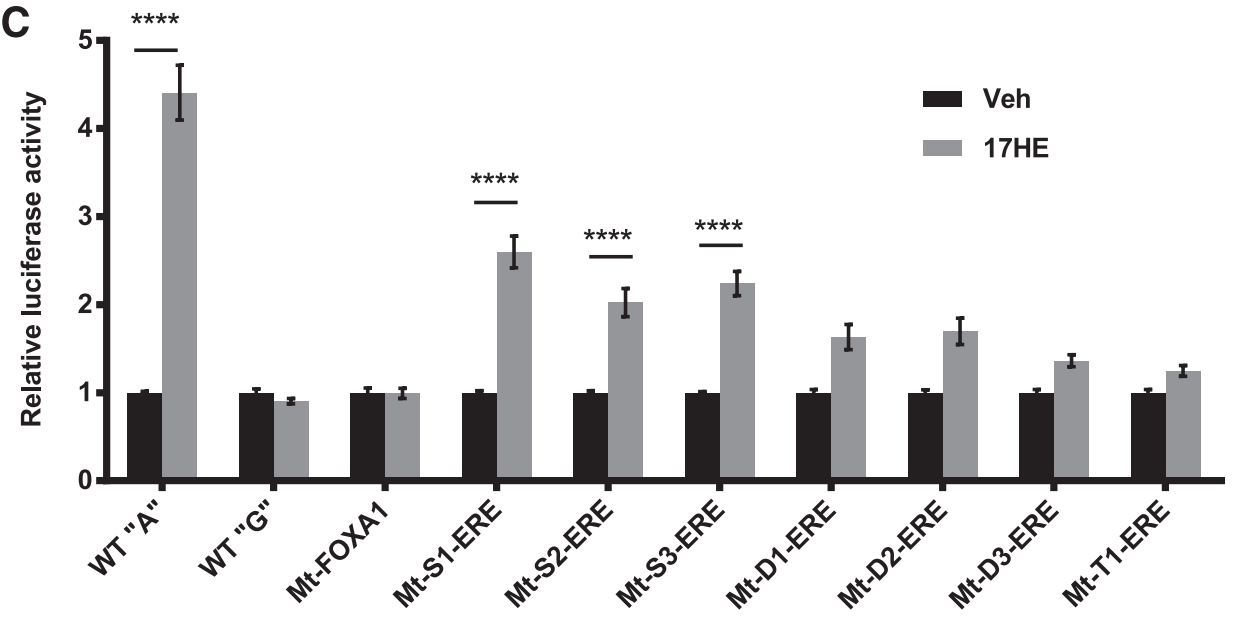

Fig. 6. EXE and 17-HE activate the $U G T 2 B 17$ proximal promoter via FOXA1 and ERE motifs. (A) Schematic diagram of the $U G T 2 B 17$ promoter from nucleotide -2 to -694 showing one FOXA1 binding site, two ERE-like half sites (3'ERE half-site and 5'ERE half-site), and an imperfect ERE-like inverted repeat. Mutations generated in these motifs within promoter constructs are indicated. (B, C) MCF-7 cells were transiently transfected with 2B17-694 wild-type (WT) or mutated (Mt) reporter constructs as well as a version of the promoter containing a naturally occurring SNP in the FOXA1 site ( $\mathrm{G}$ allele). Cells were then treated with (B) $100 \mathrm{nM}$ $\mathrm{EXE}$, (C) $10 \mathrm{nM}$ 17-HE, or vehicle for 48 hours. Relative luciferase activity was calculated as described in Materials and Methods and is presented as the fold induction over empty vector and vehicle control. The statistical significance of differences between vehicle and ligand treatments for each reporter construct, and for differences between the activities of WT, SNP variant, and Mt constructs when treated with same ligand were assessed using two-way analysis of variance and Tukey post hoc test. ( $* * P \leq 0.01$, ****P $P$ 0.0001.) more common A allele that confers efficient binding of FOXA1 (not shown). These data suggest that individuals homozygous for the $\mathrm{G}$ allele may not induce UGT2B17 in response to EXE; however, the therapeutic consequences of this, if any, will require further study, as we will discuss.

In recent work we used high-resolution chromatin immunoprecipitation analysis and mutational analysis of the UGT2B15 promoter in MCF7 cells to show that the imperfect ERE may bind predominantly to $\operatorname{ER} \alpha$, whereas the 3'ERE might be the predominant binding site for $\mathrm{AR}(\mathrm{Hu}$ et al., 2016). These previous studies used DHT and the selective androgen receptor modulator enobosarm as AR ligands. In contrast, in the current study mutational analysis of the UGT2B17 promoter in MCF7 cells suggested that all three ERE-like motifs may play equal and additive roles in the response to 17-HE-liganded AR. Moreover, the motifs are at least partially redundant, as mutation of all three motifs was required to completely eliminate the response to these drugs.

It is also notable that in our previous study, induction of UGT2B15 mRNA by DHT was only observed in $\mathrm{ER}^{+} / \mathrm{AR}^{+}$ breast cancer cell lines (e.g., MCF7) and not in $\mathrm{ER}^{-} / \mathrm{AR}^{+}$ (e.g., MDA-MB-453) cells; this together with other findings suggested that activation required the presence of both AR and ER and implied functional interaction of these receptors (Hu et al., 2016). In contrast to these previous findings, in the present study both UGT2B15 and UGT2B17 mRNA could be induced by $17-\mathrm{HE}$ in both MCF7 and MDA-MB-453 cells. The differences in the ability of different AR ligands to induce $U G T 2 B 15$ and $U G T 2 B 17$ in an $\mathrm{ER}^{-}$context suggest that 


\section{A MCF-7}

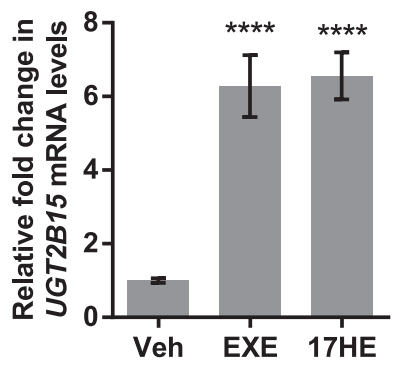

\section{B MDA-MB453}

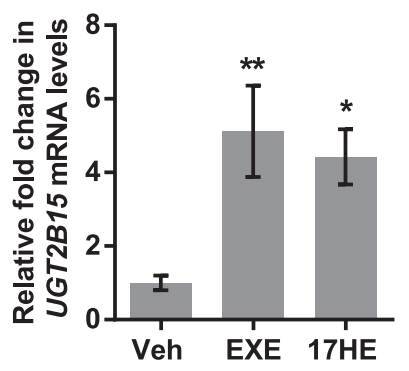

C

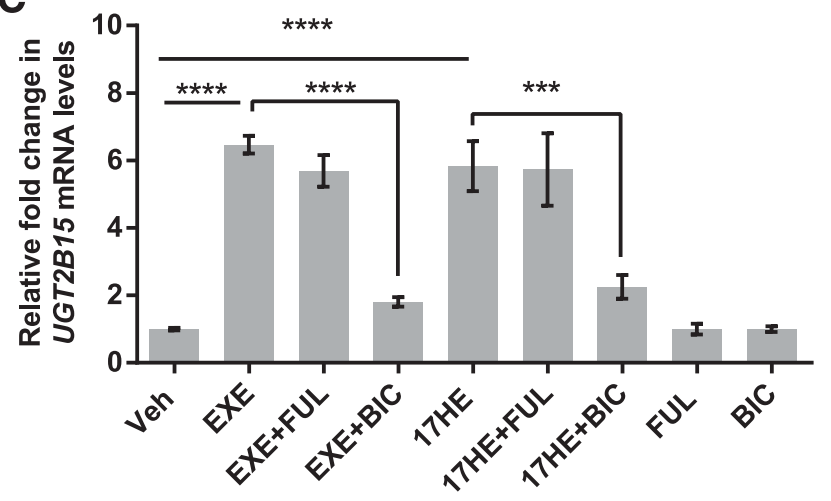

Fig. 7. EXE and 17-HE induce UGT2B15 expression in an AR- and FOXA1-dependent manner. UGT2B15 mRNA levels were measured in (A) MCF-7 and (B) MDA-MB-453 breast cancer cells after treatment EXE (100 nM) or 17-HE (10 nM) for 24 hours. (C) Androgen receptor antagonist (10 $\mu \mathrm{M}$ BIC) but not estrogen receptor antagonist (1 $\mu \mathrm{M}$ FUL) suppresses the induction of UGT2B15 mRNA expression by EXE and 17-HE in MCF7 cells. (D) siRNA targeting AR (siAR) but not siRNA targeting ER $\alpha$ (si-ER $\alpha$ ) inhibit the induction of UGT2B15 mRNA by EXE and 17-HE in MCF7 cells. (E) siRNA targeting FOXA1 also inhibits the induction of UGT2B15 mRNA by EXE and 17-HE in MCF7 cells. Data shown are the fold induction (mean \pm S.E.M.) of target mRNA levels from EXE- or 17-HE-treated cells relative to vehicle-treated cells and are derived from two independent experiments performed in triplicate. Statistical significance was assessed using one-way analysis of variance followed by Tukey's post hoc test. (*P $\leq 0.05, * * P \leq 0.01, * * * P \leq$ $0.001, * * * * P \leq 0.0001$.)

17-HE and DHT may induce different conformations of the $\mathrm{AR}$, which may in turn mediate different functional interactions with cofactors. This hypothesis will require further investigation. However, it is also likely that the UGT2B17 promoter has inherent differences in sequence/structure that allow it to respond differently to the UGT2B15 promoter. In support of this we recently found that, unlike UGT2B15, UGT2B17 can be weakly induced by DHT in MDA-MB-453 cells (not shown), albeit to a much lesser extent than by $17-\mathrm{HE}$.
This suggests that indeed the promoters can respond differently even to the same ligand.

We recently showed that $U G T 2 B 15$ can be induced by tamoxifen and its active metabolite $4-\mathrm{OH}$ tamoxifen via the ERU (Chanawong et al., 2015). Because UGT2B15 glucuronidates and inactivates 4-OH-tamoxifen, its intratumoral induction by tamoxifen generates a potential regulatory feedback loop that might impact on therapeutic efficacy and promote the acquisition of drug resistance (Chanawong et al., 
2015). The ability of UGT2B17 to conjugate 17-HE suggests the possibility of a similar regulatory feedback loop in which EXE/17-HE-mediated induction of UGT2B17 increases local inactivation of 17-HE. However, the relevance of this feedback loop to EXE efficacy in vivo depends upon whether aromatase and UGT2B17 are coexpressed.

In situ aromatization of androgens is an important mechanism for promoting growth of $\mathrm{ER}^{+}$breast cancer. Although this is considered primarily a paracrine effect with aromatase expressed in breast stromal fibroblasts and preadipocytes/ adipocytes (Zhou et al., 2001; Catalano et al., 2014; Wang et al., 2015), there is also evidence for aromatase expression in some carcinoma cells within invasive ductal carcinoma as well as in some breast cancer cell lines (Chetrite et al., 2000; Rajhans et al., 2008; Sasano et al., 2009; McNamara and Sasano, 2015; Takagi et al., 2016). Moreover, coculture of MCF7 cells with breast cancer stromal cells was able to induce aromatase expression in the former (Sasano et al., 2009). Hence, a small subset of tumors may have functionally relevant autocrine ER signaling mediated by aromatization within carcinoma cells, in addition to stromal estrogen synthesis. In such tumors, induction of UGT2B17 by EXE/ $17-\mathrm{HE}$ in carcinoma cells might lead to reduction in EXE efficacy.

It is also possible that UGT2B17 is expressed in breast tumor stromal tissue, and this requires further investigation. In support of the latter idea, UGT2B17 was found to be highly expressed in stromal fibroblasts of normal prostate (Barbier et al., 2000). Of note, AR is also expressed in breast cancer stromal cells (Lanzino et al., 2016). To date, studies of EXE metabolism in breast cancer patients with the UGT2B17 null genotype ( $12 \%$ of the population) have been restricted to measuring altered levels of 17-HE-glucuronide in plasma (Chen et al., 2016). The effect of the UGT2B17 null genotype (and indeed the effect of UGT2B17-FOXA1 motif polymorphism) on intratumoral drug levels and whether this may impact EXE efficacy remains to be examined.

The role of androgens in $\mathrm{ER} \alpha^{+} / \mathrm{AR}^{+}$breast cancer remains poorly defined, although AR expression has been associated with reduced mortality (Castellano et al., 2010; Hu et al., 2011), and androgens may antagonize estrogenic signaling by a variety of mechanisms (Hickey et al., 2012). In contrast, in $\mathrm{ER} \alpha^{-} / \mathrm{AR}^{+}$breast cancers, or those in which $\mathrm{ER} \alpha$ has been functionally ablated by long-term antiestrogen therapy, androgen signaling may be pro-proliferative (Cochrane et al., 2014; Barton et al., 2015; Zhu et al., 2016). Aromatase activity reduces local and circulating androgen levels by conversion to estrogens; EXE has been shown to significantly increase intratumoral levels of DHT in vivo (Takagi et al., 2010). EXE also increases expression of $17 \beta$-hydroxysteroid dehydrogenase 2 , which converts estradiol to the weak estrogen estrone, further reducing estrogenic signaling (Takagi et al., 2010). The combined effect of the increase in DHT, decrease in estrogen synthesis, and increased conversion of estradiol to estrone may all contribute to reduced breast cancer growth through lowering the estradiol:DHT ratio (Takagi et al., 2010).

As DHT and testosterone are primarily inactivated by UGT2B17 and UGT2B15 (Chouinard et al., 2008), the induction of these UGTs by EXE/17-HE could have an antiandrogenic effect in breast cancer cells. In particular, a reduction in DHT levels due to UGT2B17 metabolism may reduce the amount of substrate for aromatase (if these enzymes are expressed in the same cells as discussed earlier) and reduce estrogen production by this pathway. This could potentially reduce the growth of $\mathrm{ER}^{+}$breast cancers (McNamara et al., 2014), and this might even offset the potentially deleterious consequences of increased UGT2B17-mediated 17-HE clearance from tumors. However, as previously mentioned, AR appears to have context-dependent roles in breast cancer and may be influenced by ER:AR ratios and prior hormone therapy. In particular, androgens have been shown to promote growth of some $\mathrm{ER}^{+} / \mathrm{AR}^{+}$breast cancer cells in vitro and xenografts, which has been correlated to higher AR:ER expression ratios (Cochrane et al., 2014), and high AR expression has also been linked to acquired tamoxifen resistance (De Amicis et al., 2010). In such contexts the up-regulation of UGT2B17 and UGT2B15 by EXE might be directly beneficial in inhibiting androgen-driven growth pathways.

However, given the complexities of androgen and AR functions in breast cancer, it is clear that further work, including UGT perturbation in vitro and in vivo, will be required to determine whether UGT-mediated androgen inhibition is a functionally important consequence of EXE therapy, and if so by what mechanisms.

\section{Authorship Contributions}

Participated in research design: Meech, Hu, Mackenzie, Chanawong, McKinnon.

Conducted experiments: Chanawong, $\mathrm{Hu}$.

Performed data analysis: Chanawong, Meech, $\mathrm{Hu}$, Mackenzie.

Wrote or contributed to the writing of the manuscript: Meech, Chanawong, Hu, Mackenzie, McKinnon

\section{References}

Amaral C, Lopes A, Varela CL, da Silva ET, Roleira FM, Correia-da-Silva G, and Teixeira N (2015) Exemestane metabolites suppress growth of estrogen receptor-positive breast cancer cells by inducing apoptosis and autophagy: a comparative study with exemestane. Int J Biochem Cell Biol 69:183-195.

Ariazi EA, Leitão A, Oprea TI, Chen B, Louis T, Bertucci AM, Sharma CG, Gill SD, Kim HR, Shupp HA, et al. (2007) Exemestane's 17-hydroxylated metabolite exerts biological effects as an androgen. Mol Cancer Ther 6:2817-2827.

Barbier $\mathrm{O}$ and Bélanger A (2008) Inactivation of androgens by UDPglucuronosyltransferases in the human prostate. Best Pract Res Clin Endocrinol Metab 22:259-270.

Barbier O, Lapointe H, El Alfy M, Hum DW, and Bélanger A (2000) Cellular localization of uridine diphosphoglucuronosyltransferase $2 \mathrm{~B}$ enzymes in the human prostate by in situ hybridization and immunohistochemistry. J Clin Endocrinol Metab 85:4819-4826.

Barnes PJ (2004) Ceramide lances the lungs. Nat Med 10:130-131.

Barton VN, D'Amato NC, Gordon MA, Lind HT, Spoelstra NS, Babbs BL, Heinz RE, Elias A, Jedlicka P, Jacobsen BM, et al. (2015) Multiple molecular subtypes of triple-negative breast cancer critically rely on androgen receptor and respond to enzalutamide in vivo. Mol Cancer Ther 14:769-778.

Beaulieu M, Lévesque E, Hum DW, and Bélanger A (1996) Isolation and characterization of a novel cDNA encoding a human UDP-glucuronosyltransferase active on C19 steroids. J Biol Chem 271:22855-22862.

Castellano I, Allia E, Accortanzo V, Vandone AM, Chiusa L, Arisio R, Durando A Donadio M, Bussolati G, Coates AS, et al. (2010) Androgen receptor expression is a significant prognostic factor in estrogen receptor positive breast cancers. Breast Cancer Res Treat 124:607-617.

Catalano S, Giordano C, Panza S, Chemi F, Bonofiglio D, Lanzino M, Rizza P, Romeo F, Fuqua SAW, Maggiolini M, et al. (2014) Tamoxifen through GPER upregulates aromatase expression: a novel mechanism sustaining tamoxifen-resistant breast cancer cell growth. Breast Cancer Res Treat 146:273-285.

Chanawong A, Hu DG, Meech R, Mackenzie PI, and McKinnon RA (2015) Induction of UDP-glucuronosyltransferase 2B15 gene expression by the major active metabolites of tamoxifen, 4-hydroxytamoxifen and endoxifen, in breast cancer cells. Drug Metab Dispos 43:889-897.

Chen F, Ritter JK, Wang MG, McBride OW, Lubet RA, and Owens IS (1993) Characterization of a cloned human dihydrotestosterone/androstanediol UDPglucuronosyltransferase and its comparison to other steroid isoforms. Biochemistry 32:10648-10657.

Chen SM, Atchley DH, Murphy MA, Gurley BJ, and Kamdem LK (2016) Impact of UGT2B17 gene deletion on the pharmacokinetics of 17-hydroexemestane in healthy volunteers. $J$ Clin Pharmacol 56:875-884

Chetrite GS, Cortes-Prieto J, Philippe JC, Wright F, and Pasqualini JR (2000) Comparison of estrogen concentrations, estrone sulfatase and aromatase activities 
in normal, and in cancerous, human breast tissues. J Steroid Biochem Mol Biol 72 : $23-27$.

Chouinard S, Yueh MF, Tukey RH, Giton F, Fiet J, Pelletier G, Barbier O, and Bélanger A (2008) Inactivation by UDP-glucuronosyltransferase enzymes: the end of androgen signaling. J Steroid Biochem Mol Biol 109:247-253.

Cochrane DR, Bernales S, Jacobsen BM, Cittelly DM, Howe EN, D'Amato NC, Spoelstra NS, Edgerton SM, Jean A, Guerrero J, et al. (2014) Role of the androgen receptor in breast cancer and preclinical analysis of enzalutamide. Breast Cancer Res 16:R7.

Coombes RC, Hall E, Gibson LJ, Paridaens R, Jassem J, Delozier T, Jones SE, Alvarez I, Bertelli G, Ortmann O, et al.; Intergroup Exemestane Study (2004) A randomized trial of exemestane after two to three years of tamoxifen therapy in postmenopausal women with primary breast cancer. N Engl J Med 350:1081-1092.

De Amicis F, Thirugnansampanthan J, Cui Y, Selever J, Beyer A, Parra I, Weigel NL, Herynk MH, Tsimelzon A, Lewis MT, et al. (2010) Androgen receptor overexpression induces tamoxifen resistance in human breast cancer cells. Breast Cancer Res Treat 121:1-11.

Evans TR, Di Salle E, Ornati G, Lassus M, Benedetti MS, Pianezzola E, and Coombes RC (1992) Phase I and endocrine study of exemestane (FCE 24304), a new aromatase inhibitor, in postmenopausal women. Cancer Res 52:5933-5939.

Gauthier-Landry L, Bélanger A, and Barbier O (2015) Multiple roles for UDP glucuronosyltransferase (UGT)2B15 and UGT2B17 enzymes in androgen metabolism and prostate cancer evolution. J Steroid Biochem Mol Biol 145:187-192.

Goss PE (2003) Emerging role of aromatase inhibitors in the adjuvant setting. Am J Clin Oncol 26:S27-S33.

Goth-Goldstein R, Stampfer MR, Erdmann CA, and Russell M (2000) Interindividual variation in CYP1A1 expression in breast tissue and the role of genetic polymorphism. Carcinogenesis 21:2119-2122.

Hickey TE, Robinson JL, Carroll JS, and Tilley WD (2012) Minireview: the androgen receptor in breast tissues: growth inhibitor, tumor suppressor, oncogene? Mol Endocrinol 26:1252-1267.

Hu DG, Gardner-Stephen D, Severi G, Gregory PA, Treloar J, Giles GG, English DR Hopper JL, Tilley WD, and Mackenzie PI (2010) A novel polymorphism in a forkhead box A1 (FOXA1) binding site of the human UDP glucuronosyltransferase $2 \mathrm{~B} 17$ gene modulates promoter activity and is associated with altered levels of circulating androstane-3 $\alpha, 17 \beta$-diol glucuronide. Mol Pharmacol 78:714-722.

Hu DG and Mackenzie PI (2009) Estrogen receptor alpha, fos-related antigen-2, and c-Jun coordinately regulate human UDP glucuronosyltransferase $2 \mathrm{~B} 15$ and 2B17 expression in response to $17 \beta$-estradiol in MCF-7 cells. Mol Pharmacol 76:425-439.

Hu DG and Mackenzie PI (2010) Forkhead box protein A1 regulates UDPglucuronosyltransferase 2B15 gene transcription in LNCaP prostate cancer cells. Drug Metab Dispos 38:2105-2109.

Hu DG, Selth LA, Tarulli GA, Meech R, Wijayakumara D, Chanawong A, Russell R, Caldas C, Robinson JL, Carroll JS, et al. (2016) Androgen and estrogen receptors in breast cancer coregulate human UDP-glucuronosyltransferases 2B15 and 2B17. Cancer Res 76:5881-5893.

Hu R, Dawood S, Holmes MD, Collins LC, Schnitt SJ, Cole K, Marotti JD, Hankinson SE, Colditz GA, and Tamimi RM (2011) Androgen receptor expression and breast cancer survival in postmenopausal women. Clin Cancer Res 17:1867-1874.

Jones NR and Lazarus P (2014) UGT2B gene expression analysis in multiple tobacco carcinogen-targeted tissues. Drug Metab Dispos 42:529-536.

Kamdem LK, Flockhart DA, and Desta Z (2011) In vitro cytochrome P450-mediated metabolism of exemestane. Drug Metab Dispos 39:98-105.

Lanzino M, Campana A, Giordano C, Barone I, Bonofiglio D, Catalano S, and Andò S (2016) Expression and function of androgen receptor in human breast cancerassociated fibroblasts: may androgens shape breast tumor microenvironment? (Abstract) FASEB J 30(Suppl):698.9.

Lévesque E, Beaulieu M, Green MD, Tephly TR, Bélanger A, and Hum DW (1997) Isolation and characterization of UGT2B15(Y85): a UDP-glucuronosyltransferase encoded by a polymorphic gene. Pharmacogenetics 7:317-325.

Livak KJ and Schmittgen TD (2001) Analysis of relative gene expression data using real-time quantitative PCR and the 2- $\Delta \Delta_{\mathrm{T}}^{\mathrm{C}}$ method. Methods 25:402-408.

Loibl S, Müller BM, von Minckwitz G, Schwabe M, Roller M, Darb-Esfahani S, Ataseven B, du Bois A, Fissler-Eckhoff A, Gerber B, et al. (2011) Androgen recepto expression in primary breast cancer and its predictive and prognostic value in patients treated with neoadjuvant chemotherapy. Breast Cancer Res Treat 130 $477-487$.

Lønning PE and Geisler J (2008) Experience with exemestane in the treatment of early and advanced breast cancer. Expert Opin Drug Metab Toxicol 4:987-997.

McNamara KM, Moore NL, Hickey TE, Sasano H, and Tilley WD (2014) Complexities of androgen receptor signalling in breast cancer. Endocr Relat Cancer 21: T161-T181.

McNamara KM and Sasano H (2015) The intracrinology of breast cancer. J Steroid Biochem Mol Biol 145:172-178.

Miller WR, Bartlett J, Brodie AM, Brueggemeier RW, di Salle E, Lønning PE, Llombart A, Maass N, Maudelonde T, Sasano H, et al. (2008) Aromatase inhibitors: are there differences between steroidal and nonsteroidal aromatase inhibitors and do they matter? Oncologist 13:829-837.

Moinfar F, Okcu M, Tsybrovskyy O, Regitnig P, Lax SF, Weybora W, Ratschek M, Tavassoli FA, and Denk H (2003) Androgen receptors frequently are expressed in breast carcinomas: potential relevance to new therapeutic strategies. Cancer 98 $703-711$
Nakamura A, Nakajima M, Yamanaka H, Fujiwara R, and Yokoi T (2008) Expression of UGT1A and UGT2B mRNA in human normal tissues and various cell lines. Drug Metab Dispos 36:1461-1464.

Ohno S and Nakajin S (2009) Determination of mRNA expression of human UDPglucuronosyltransferases and application for localization in various human tissues by real-time reverse transcriptase-polymerase chain reaction. Drug Metab Dispos 37:32-40.

Penning TM and Byrns MC (2009) Steroid hormone transforming aldo-keto reductases and cancer. Ann N Y Acad Sci 1155:33-42.

Rajhans R, Nair HB, Nair SS, Cortez V, Ikuko K, Kirma NB, Zhou D, Holden AE, Brann DW, Chen S, et al. (2008) Modulation of in situ estrogen synthesis by proline-, glutamic acid-, and leucine-rich protein-1: potential estrogen receptor autocrine signaling loop in breast cancer cells. Mol Endocrinol 22:649-664

Rodriguez M and Potter DA (2013) Cytochrome P450 1A1 regulates breast cancer cell proliferation and survival. Mol Cancer Res 11:780-792.

Ruddock LW and Molinari M (2006) N-glycan processing in ER quality control. $J$ Cell Sci 119:4373-4380.

Sasano H, Miki Y, Nagasaki S, and Suzuki T (2009) In situ estrogen production and its regulation in human breast carcinoma: from endocrinology to intracrinology. Pathol Int 59:777-789.

Simpson MA, Wilson CM, Furcht LT, Spicer AP, Oegema, JrTR, and McCarthy JB (2002) Manipulation of hyaluronan synthase expression in prostate adenocarcinoma cells alters pericellular matrix retention and adhesion to bone marrow endothelial cells. J Biol Chem 277:10050-10057.

Starlard-Davenport A, Lyn-Cook B, and Radominska-Pandya A (2008) Identification of UDP-glucuronosyltransferase 1A10 in non-malignant and malignant human breast tissues. Steroids 73:611-620.

Sun D, Chen G, Dellinger RW, Sharma AK, and Lazarus P (2010) Characterization of 17-dihydroexemestane glucuronidation: potential role of the UGT2B17 deletion in exemestane pharmacogenetics. Pharmacogenet Genomics 20:575-585.

Sun D, Liu Y, McCloskey DE, and Lazarus P (2011) Abstract 712: Characterization of exemestane metabolic pathways (Abstract). Cancer Res 71(Suppl):712 DOI 10.1158/1538-7445.AM2011-712.

Takagi K, Miki Y, Nagasaki S, Hirakawa H, Onodera Y, Akahira J, Ishida T, Watanabe M, Kimijima I, Hayashi S, et al. (2010) Increased intratumoral androgens in human breast carcinoma following aromatase inhibitor exemestane treatment. Endocr Relat Cancer 17:415-430.

Takagi M, Miki Y, Miyashita M, Hata S, Yoda T, Hirakawa H, Sagara Y, Rai Y, Ohi Y, Tamaki K, et al. (2016) Intratumoral estrogen production and actions in luminal A type invasive lobular and ductal carcinomas. Breast Cancer Res Treat 156:45-55. Tchernof A, Lévesque E, Beaulieu M, Couture P, Després JP, Hum DW, and Bélanger A (1999) Expression of the androgen metabolizing enzyme UGT2B15 in adipose tissue and relative expression measurement using a competitive RT-PCR method. Clin Endocrinol (Oxf) 50:637-642.

Thibaudeau J, Lépine J, Tojcic J, Duguay Y, Pelletier G, Plante M, Brisson J, Têtu B, Jacob S, Perusse L, et al. (2006) Characterization of common UGT1A8, UGT1A9, and UGT2B7 variants with different capacities to inactivate mutagenic 4-hydroxylated metabolites of estradiol and estrone. Cancer Res 66:125-133.

van de Velde CJ, Rea D, Seynaeve C, Putter H, Hasenburg A, Vannetzel JM, Paridaens R, Markopoulos C, Hozumi Y, Hille ET, et al. (2011) Adjuvant tamoxifen and exemestane in early breast cancer (TEAM): a randomised phase 3 trial. Lancet 377:321-331.

Walker G, Xenophontos M, Chen L, and Cheung K (2013) Long-term efficacy and safety of exemestane in the treatment of breast cancer. Patient Prefer Adherence 7 : $245-258$

Wang X, Sang X, Diorio C, Lin SX, and Doillon CJ (2015) In vitro interactions between mammary fibroblasts (Hs 578Bst) and cancer epithelial cells (MCF-7) modulate aromatase, steroid sulfatase and $17 \beta$-hydroxysteroid dehydrogenases. Mol Cell Endocrinol 412:339-348.

Wijayakumara DD, Hu DG, Meech R, McKinnon RA, and Mackenzie PI (2015) Regulation of human UGT2B15 and UGT2B17 by miR-376c in prostate cancer cell lines. $J$ Pharmacol Exp Ther 354:417-425.

Yin YD, Fu M, Brooke DG, Heinrich DM, Denny WA, and Jamieson SMF (2014) The Activity of SN33638, an inhibitor of AKR1C3, on testosterone and 17 $\beta$-estradiol production and function in castration-resistant prostate cancer and ER-positive breast cancer. Front Oncol 4:159.

Yue W, Wang JP, Hamilton CJ, Demers LM, and Santen RJ (1998) In situ aromatization enhances breast tumor estradiol levels and cellular proliferation. Cancer Res 58:927-932.

Zhou J, Gurates B, Yang S, Sebastian S, and Bulun SE (2001) Malignant breast epithelial cells stimulate aromatase expression via promoter II in human adipose fibroblasts: an epithelial-stromal interaction in breast tumors mediated by CCAAT/enhancer binding protein beta. Cancer Res 61:2328-2334.

Zhu A, Li Y, Song W, Xu Y, Yang F, Zhang W, Yin Y, and Guan X (2016) Antiproliferative effect of androgen receptor inhibition in mesenchymal stem-like triple-negative breast cancer. Cell Physiol Biochem 38:1003-1014.

Address correspondence to: Dr. Robyn Meech, Department of Clinical Pharmacology and Flinders Centre for Innovation in Cancer, School of Medicine, Flinders University, Bedford Park SA 5042, Australia. E-mail: robyn.meech@flinders.edu.au 